\title{
Liquid phase chromatographic methods applied to determine emerging contaminants in environmental samples
}

httsp://doi.org/10.21698/rjeec.2020.102

Review

\section{VASILE-ION IANCU ${ }^{1}$, JANA PETRE**1, TOMA GALAON ${ }^{1}$, GABRIEL-VALENTIN SERBAN ${ }^{1}$, MARCELA NICULESCU ${ }^{1}$, FLORENTINA LAURA CHIRIAC ${ }^{1}$, ROXANA-ELENA SCUTARIU $^{1}$, STEFANIA GHEORGHE ${ }^{1}$, GABRIEL-LUCIAN RADU ${ }^{2}$}

\author{
${ }^{I}$ National Research and Development Institute for Industrial Ecology-ECOIND, Drumul Podu Dambovitei \\ Street, 71-73, Sector 6, Bucharest, *janapetre@gmail.com, \\ ${ }^{2}$ University Politehnica Bucharest, Faculty of Applied Chemistry and Materials Science, 1-7 Polizu Str., \\ 011061, Bucharest, Romania
}

\section{Abstract}

Emerging contaminants are a heterogeneous group of chemicals that includes daily personal care products and pharmaceuticals (PPCPs), flame retardants, endocrine disrupting chemicals (EDCs) and nanoparticles (NPs) present in environment which are unregulated. In this review we present the methods of analysis conducted by INCD-ECOIND regarding some classes of emerging contaminants (neonicotinoid pesticides, beta-blocker drugs) which are not regulated by the legislation, in different types of environmental samples (wastewater, surface water). The present review presents the selective solid phase extraction (SPE) methods used for isolation of the targeted compounds from aqueous matrices and also the main instrumental parameters of the separation and detection process. After extraction, the compounds were subjected to liquid phase chromatographic separation with mass spectrometric detection (UHPLC-MS/MS). Finally, the methods were applied in the determination of compounds from different categories of water, carrying out studies on the efficiency of elimination of compounds in several municipal wastewater treatment plants (WWTPS). In addition, the impact of the treatment plants on some receiving surface water used to obtain drinking water was studied.

Keywords: emerging contaminants (neonicotinoid, beta-blockers), SPE-UHPLC-MS/MS, environmental samples (surface water, influent/effluent)

\section{INTRODUCTION}

Global continuous industrial development generated the environmental presence of a large variety of new chemicals applied in daily anthropic practices. These substances, organic and inorganic compounds, are considered to be a polluting factor and cause concern for society [1]. A number of families of compounds, such as pharmaceuticals and personal care products (PPCPs), flame retardants, nanoparticles or endocrine disrupting chemicals (EDCs) among many substances, form this heterogeneous group, often referred as "emerging contaminants" (Figure 1). These substances are ubiquitous and present potential risks to human health, although their toxicological effects are not always known [2].

Neonicotinoids are one of the main insecticides applied globally; actually, they become the insecticides most used in the global market. The major commercial neonicotinoids (acetamiprid, imidacloprid, clothianidin, dinotefuran, nitenpyram, thiacloprid, and thiamethoxam) are classified into three families: $\mathrm{N}$-nitroguanidines, nitro-methylene's and N-cyan amidines [3]. Their use has been registered for more than 140 different crops in over 120 countries, making them the most used insecticides worldwide. They got a lot of attention because they were found to cause damage to pollinators, and this would lead to the death of bee colonies [4]. Neonicotinoids are generally toxic to insects in minute quantities; for example, the LD50 (a dose that kills $50 \%$ of individuals) for ingestion of imidacloprid and clothianidin in honey bees is 3.7-81 ng and $4 \mathrm{ng}$ per insect, respectively.In the environment, neonicotinoids are highly water- soluble compounds being also highly persistent (Table 1) 


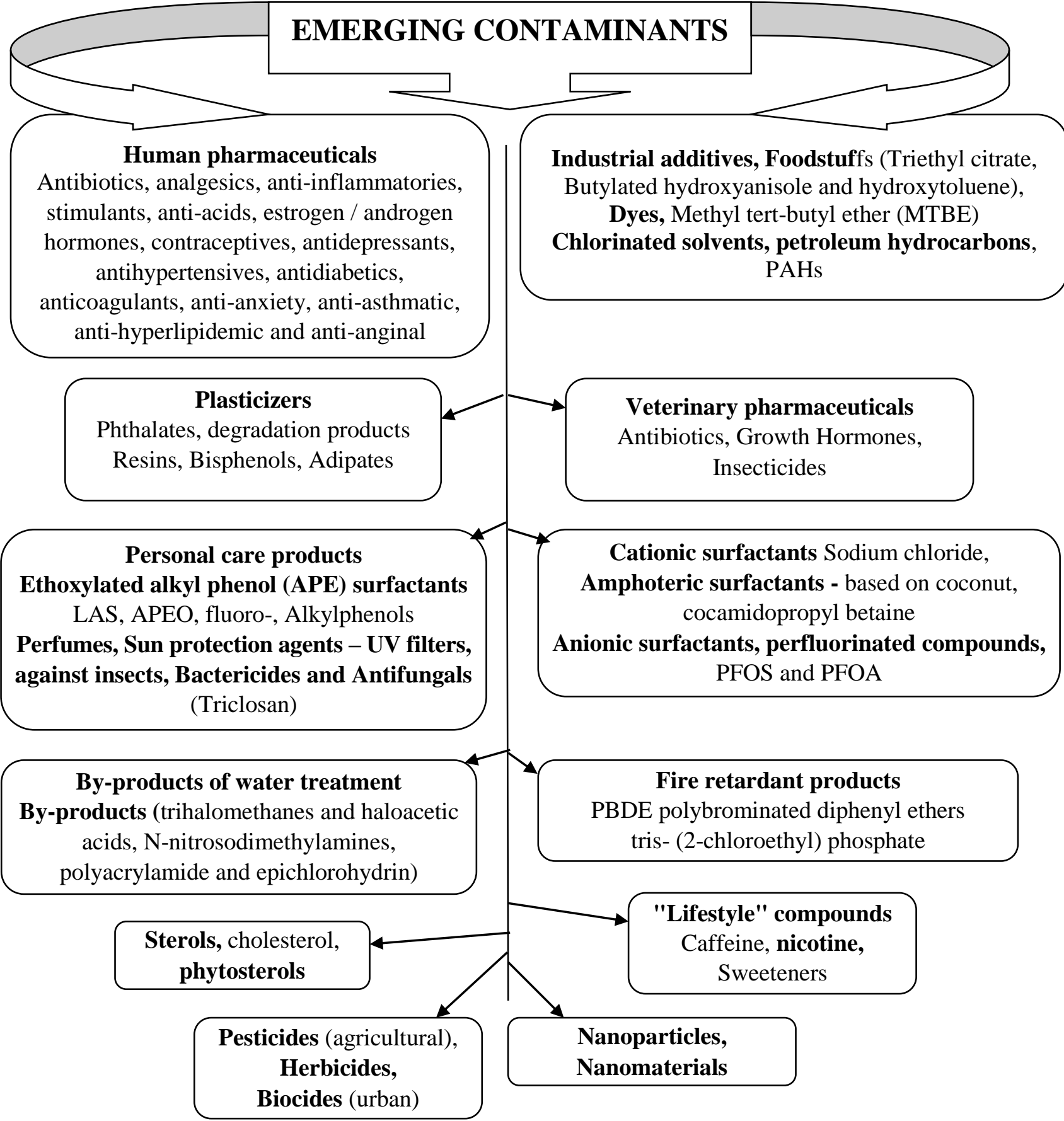

Figure 1. Schematic representation of the main chemical classes of emerging organic contaminants in the environmental samples

Table 1. Chemical properties and persistence of neonicotinoid insecticides in the environment [5-7]

\begin{tabular}{|c|c|c|c|c|c|c|}
\hline Compound & $\begin{array}{c}\text { Water } \\
\text { solubility } \\
(\mathrm{mg} / \mathrm{L}) 20^{\circ} \mathrm{C}\end{array}$ & $\begin{array}{l}\text { Lipophilicity } \\
\text { (logKow) }\end{array}$ & $\begin{array}{l}\text { Soil affinity } \\
(\log K o c)\end{array}$ & $\begin{array}{c}\text { Hydrolysis in } \\
\text { water; } \mathrm{pH} 9 \\
\text { (DT50 in days) } \\
\text { a }\end{array}$ & $\begin{array}{c}\text { Photolysis in } \\
\text { water (DT50 } \\
\text { in days) }\end{array}$ & $\begin{array}{l}\text { Half-life in } \\
\text { soil } \\
\text { DT50(days) }\end{array}$ \\
\hline Dintotefuran & 39830 & -0.55 & 1.41 & Stable & $<2$ & $50-100$ \\
\hline Imidacloprid & 610 & 0.57 & 2.19 & Stable, $>1$ an & $<1$ & $104-228$ \\
\hline Nitenpyram & 590000 & -0.66 & 1.78 & Stable 2.9 & Unavailable & $1-15$ \\
\hline Thiamethoxam & 4100 & -0.13 & 1.75 & Stable 11.5 & $2.7-39.5$ & 50 \\
\hline Chlotianidin & 340 & 0.91 & 2.08 & Stable 14.4 & 0.1 & 545 \\
\hline Acetamipride & 2950 & 0.8 & 2.3 & Stable 420 & 34 & 3 \\
\hline
\end{tabular}

${ }^{\mathrm{a}}$ at $\mathrm{pH}$ 4-7 the compounds are stable, but at $\mathrm{pH} 9$ hydrolysis may occur 
In 2015, neonicotinoid insecticides have been included in the watch list of substances for a European Union monitoring program (495/2015/ EU, LOD 9 ng/L) [8]. In 2018 the European Commission approved the use of imidacloprid, thiamethoxam and clothianidin treated seeds only in permanent greenhouse. Thus, the use of these substances in agriculture for agricultural purposes was forbidden [9]. During last decade, pollution with neonicotinoid insecticides has been observed in surface water, many of these receiving treated effluents from wastewater treatment plants. Wastewater represents a potential source of neonicotinoid insecticides in environment that has not received sufficient attention yet [10]. Neonicotinoids are used in urban applications such as pet flea treatment, horticulture and house pet pest control products. A few studies have detected imidacloprid in wastewater, showing that treated effluents can contribute to neonicotinoid discharge into receiving rivers. In Spain, imidacloprid was detected in wastewater influent and effluent samples at concentrations ranging from 1.4165.7 ng/L [11]. In USA (Oregon), imidacloprid was detected in $9.8 \%$ effluents samples from WWTP with an average concentration of 270 $\mathrm{ng} / \mathrm{L}[12]$.

Beta-blockers are weak base compounds (secondary amines) with an acidity constant (pKa) of about 9, which are protonated to a neutral $\mathrm{pH}$ (pH 6-8) in the environment and have a hydrophilic character [13]. The selected compounds and their physical-chemical properties are presented in Table $2[13,14]$. Log Dow is the logarithm of the distribution coefficient.

Table 2. Structures and chemical properties of selected beta-blockers

\begin{tabular}{ccccc}
\hline Compound & pKa & $\begin{array}{c}\text { Molar mass } \\
(\mathrm{g} / \mathrm{mol})\end{array}$ & $\begin{array}{c}\text { Log Dow } \\
\mathrm{pH} \approx 7.45^{*}\end{array}$ & $\begin{array}{c}\text { Log Dow } \\
\text { at } \mathrm{pH} \mathrm{10}\end{array}$ \\
\hline Atenolol & 9.60 & 266.3 & -1.8 & 0.26 \\
Propranolol & 9.53 & 259.34 & 0.36 & 2.42 \\
Betaxolol & 9.40 & 307.4 & 0.31 & 2.37 \\
Nadolol & 9.69 & 309.4 & -1.44 & 0.67 \\
Pindolol & 9.25 & 248.3 & -0.53 & 1.53 \\
Bisoprolol & 9.67 & 325.4 & -0.03 & 2.03 \\
4-hydroxy & 9.91 & 275.34 & - & - \\
propranolol & & &
\end{tabular}

*pKa from Chemicalize (http://www.chemicalize.org/) [14], Log Dow values (pH dependent noctanol -water distribution coefficient of ionizable compounds) are given for $\mathrm{pH} 7.45$ and 10 .

Among emerging contaminants beta-blockers are widely used in therapy against hypertension and heart failure. As an example, 100 to 250 tons of beta-blockers are consumed each year in Germany [15]. Large quantities of pharmaceuticals are discharged directly and continuously into the rivers through untreated wastewaters and through effluents from conventional wastewater treatment plants due to incomplete elimination, or terrestrial run-off [16]. After consumption, beta-blockers are excreted via urine in non-metabolized forms as follows: atenolol (>85\%), and nadolol (100\%). Betaxolol and propranolol are largely metabolized, at higher than $80 \%$. Bisoprolol is metabolized both in urine and in feces in similar percentages - approx. 50\%/50\% [17]. The presence of antihypertensives in the environment can lead to toxicological effects on non-target organisms. For example, Maszkowska et al. pointed out that beta-blockers belong to the class of Endocrine Disruptive Compounds, since they can disrupt testosterone levels in male organisms [18]. These drugs and their metabolites are discharged through municipal wastewater treatment plants, through hospital wastewater as well as wastewater from the pharmaceutical industry. The effluent from wastewater in the pharmaceutical industry is not regulated in Romania. Beta-blockers have been detected in wastewater and surface waters by some researchers worldwide $[19,20]$. The most widely used analytical technique for determination of pharmaceutical compounds including beta blockers in environmental waters is liquid chromatography coupled to tandem 
mass spectrometry (LC-MS/MS) because of its high specificity and sensitivity [20-25]. The metabolites of beta-blockers are rarely investigated in wastewater or surface water due to lack of standards or lack of adequate methods for analyzing these emerging contaminants. The insufficient removal of beta-blockers from wastewater may contribute to surface water contamination. For example, removal rates of atenolol by the activated-sludge technology in wastewater treatment plants range from 10\% [26] to $79 \%$ [13] and even $83 \%$ [15]. Removal of propranolol in wastewater treatment plants ranges from $28 \%$ to $96 \%[13,15]$. Beta-blockers are weakly basic (secondary amines) compounds with an acidity constant (p-Ka) of about 9, which are protonated at neutral environmental $\mathrm{pH}$ ( $\mathrm{pH}$ 6-8) and they have a hydrophilic character [15].

Organic contaminants such as pharmaceutical compounds (beta-blockers) from WWTP effluents are discharged into surface water, so they can affect the life of aquatic microorganisms. On the other hand, the receiving surface waters are used as sources of drinking water. Therefore, it is important that the WWTP removal rates be investigated to have the possibility to evaluate the potential impact of WWTPs on surface waters. The emerging compound class also contains betablockers (nadolol, bisoprolol, betaxolol, propranolol, atenolol, pindolol, 4-hydroxy propranolol), neonicotinoids (nitenpyram, thiamethoxam, clothianidin, acetamiprid, dinotefuran, imidacloprid).

This review aimed to present the main analytical methods (SPE-LC-MS/MS) used for determination of some classes of emerging contaminants in environmental samples (surface water, influent and effluent from wastewater treatment plants). Thus, the main operating parameters for SPE extraction, (LC) liquid chromatographic separation and (MS) mass spectrometric detection were presented. Finally, we presented the results of the application of the methods for determining the contaminants from various urban wastewater treatment plants and rivers.

\section{EXPERIMENTAL PART}

$S P E-L C-M S / M S$ method for neonicotinoids detection in waste and river water

The method of analysis of the compounds of acquisition mode. Two MRM transitions were interest has been previously published [25, 27, used, one for quantitation (quantifier) and 28]. Neonicotinoid determination was performed another for analyte confirmation (qualifier). using an Agilent 1260 liquid chromatograph in Agilent Technologies Mass-Hunter software was tandem with the Agilent quadrupole 6410B triple mass spectrometer provided with the ionization electrospray ESI source in the positive mode. Detection was realized by Multiple Reaction Monitoring (MRM) used for data acquisition and quantitative determinations. The LC and MS/MS working parameters are presented in Table 3.

Table 3. LC and MS/MS operating parameters for determination of neonicotinoids in water samples Agilent 1260 LC Agilent 6410B triple quadrupole mass spectrometer

Column: Hypersil Gold 100 x $2.1 \mathrm{~mm}, 3 \mu \mathrm{m}$

Column temperature: $20^{\circ} \mathrm{C}$

Injected volume: $10 \mu \mathrm{L}$

Mobile phase: ACN:water with $0.2 \% \mathrm{HCOOH}$ Mobile phase flow rate: $0.2 \mathrm{~mL} / \mathrm{min}$

Elution: in gradient 0-2 min 10\% B, 2-9 min $10-80 \%$ B, 9-13 min $80 \% \mathrm{~B}$, and equilibration 6 min with $10 \% \mathrm{~B}$.
Ionization mode: ESI+

Gas temperature: $300^{\circ} \mathrm{C}$

Drying gas flow rate: $8 \mathrm{~L} / \mathrm{min}$

Nebulizer pressure: $40 \mathrm{psi}$

Capil lary voltage: $3500 \mathrm{~V}$

Collision energy: 4-20 V

Fragmentation voltage: $45-100 \mathrm{~V}$

Dwell time: $100 \mathrm{msec}$

MRM: 2 transitions for each compound

Cell acceleration voltage: $7 \mathrm{~V}$ 
For each compound, two signals were monitored, corresponding to the transition between the precursor ion and the two most

\section{Sample preparation for neonicotinoid extraction}

The processing of samples of wastewater $(500$ $\mathrm{ml})$ and surface $(1000 \mathrm{ml})$ was done by SPE method. The samples were isolated with AutoTrace 280 solid-phase extractor equipment (Dionex, Thermo-Scientific). First, the samples were filtered through fiberglass membrane $(0.45$ $\mu \mathrm{m})$ to remove suspended materials that may block the SPE cartridge. Then the SPE cartridges were conditioned with methanol and ultrapure water. The water samples were

Wastewater sampling for neonicotinoid detection In some studies, carried out by INCD ECOIND in 2018, the presence and behavior of neonicotinoids in wastewater and in surface water taken from the Bucharest WWTP, was abundant product ions. The most abundant one was used for quantification while the other one was used for confirmation.

percolated through the SPE material to retain the analytes. Removal of traces of water was achieved by passing a nitrogen stream through the cartridge for 20 minutes. Then the analytes were eluted from the cartridge with methyl alcohol. The obtained extract was evaporated in a water bath at $50^{\circ} \mathrm{C}$ to dry and the residue was resumed with the mobile phase $(1 \mathrm{ml}$ acetonitrile: formic acid $0.2 \%, 90 / 10, \mathrm{v} / \mathrm{v})$.

evaluated [25, 27, 28]. Composite samples were taken from the treatment plant in Bucharest in November 22-26, 2017, from influent, decanted and effluent.

Analysis method of beta-blockers in wastewater samples

The analysis of beta-blocking compounds was performed using a previously published SPELC-MS/MS method [17]. The method for simultaneous analysis of 6 beta-blockers and one metabolite, developed within a "Nucleu" project, has been validated and verified to be applied for the detection of these compounds from wastewater samples in Romania. For this purpose, are presented the chromatographic parameters of operation and processing of water samples. The optimum parameters of separation by liquid chromatography (LC) of the target analytes, established experimentally, are presented in Table 4, as well as the operating parameters of the mass spectrometer for the detection of the compounds of interest.

Table 4. LC and MS/MS Operating parameters for determination of beta blockers in water samples Agilent 1260 LC Agilent 6410B triple quadrupole mass spectrometer

Column: Luna C18(2) $(150 \times 2 \mathrm{~mm}, 3 \mu \mathrm{m}) \quad$ Ionization mode: ESI+

Gas temperature: $300^{\circ} \mathrm{C}$

Column temperature: $45^{\circ} \mathrm{C}$

Drying gas flow rate: $8 \mathrm{~L} / \mathrm{min}$

Nebulizer pressure: 45 psi

Injected volume: $5 \mu 1$

Capillary voltage: $3650 \mathrm{~V}$

Collision energy: 10-35 V

Mobile phase: $0.1 \% \mathrm{HCOOH}(\mathrm{A}) / \mathrm{MeOH}(\mathrm{B})$

Fragmentation voltage: $95-140 \mathrm{~V}$

Mobile phase flow rate: $0.2 \mathrm{~mL} / \mathrm{min}$

Dwell time: $50-200 \mathrm{msec}$

Elution: in gradient: 0-4 min 5\% B, 4-8 min 5-

MRM: 2 transitions for each compound $80 \%$ B , 8-14.5 min 80\% B, equilibration 6 min Cell acceleration voltage: $7 \mathrm{~V}$ with $5 \% \mathrm{~B}$.

The compounds were analyzed with a 1260 LC system (Agilent) coupled with the quadrupole MS/MS 6410B triple mass spectrometer (Agilent). First, the compounds were separated on a C18 Luna column at a constant temperature of $45^{\circ} \mathrm{C}$ using a mobile phase gradient consisting of $0.1 \%$ formic acid and methanol. The volume of sample extract injected each time was $5 \mu \mathrm{L}$ in a mobile phase flow with a constant flow rate of $0.2 \mathrm{~mL} / \mathrm{min}$. Then, the molecules of each 
compound were introduced into the ESI electrospray source of the mass spectrometer, where they were ionized, by accepting a proton, at the precursor molecular ion $\left([\mathrm{M}-\mathrm{H}]^{+}\right)$. The determination of the compounds was based on two MRM transitions between the precursor ion and the most abundant product ions, one for quantification and the other for confirmation.

The pretreatment of water samples has been enhanced by an automatic extraction system in the solid phase Auto-Trace 280 (Dionex). SPE Strata X $(500 \quad \mathrm{mg} / 6 \mathrm{~mL}) \quad$ cartridges (Phenomenex) were used to extract beta blockers from wastewater. First the water samples $(250 \mathrm{ml})$ were filtered on glass fiber ( $0.45 \mathrm{um})$ to remove the suspended solids, then their $\mathrm{pH}$ was adjusted to 10 with $0.2 \% \mathrm{NH} 4 \mathrm{OH}$ (Table 5). The adsorbent material was conditioned with methanol and pure water $\mathrm{pH}$ 10. The compounds were retained in the sorbent by automatic loading of the samples through cartridges. Then, synthetic air was passed through the sorbent for $20 \mathrm{~min}$ to dry, after which the elution was made with methanol. The resulting extract was evaporated under nitrogen at $50^{\circ} \mathrm{C}$. The compounds were resumed with 1 $\mathrm{ml}$ of mobile phase.

Table 5. Solid phase extraction parameters in the automatic Dionex 280 Autotrace

\begin{tabular}{cl}
\hline Crt. No. & Name of the stage \\
\hline 1 & Cartridge conditioning with $2 \times 4 \mathrm{~mL} \mathrm{MeOH}$ \\
2 & Cartridge conditioning with $2 \times 4 \mathrm{~mL} \mathrm{NH} 4 \mathrm{OH} \mathrm{pH} 10$ \\
3 & Load 250ml sample of wastewater in cartridge \\
4 & Cartridge wash with $2 \times 5 \mathrm{~mL}$ pure water \\
5 & $\begin{array}{l}\text { Dry the cartridge with gas for } 20 \text { minutes } \\
\text { Elution } 6:\end{array}$ \\
& $\begin{array}{l}\text { - wetting cartridge with } 2 \times 2 \mathrm{~mL} \mathrm{MeOH} \text { and extract collection } \\
\text { - cartridge elution with } 2 \mathrm{ml} \text { methanol, extract collection }\end{array}$ \\
\end{tabular}

Wastewater sampling for beta-blockers detection For the analysis of the residues of beta-blockers there were collected composite samples (24h) of influent and effluent from 3 municipal wastewater treatment plants (Focsani, Braila and Targu-Jiu), in 3 successive days, in September 2018.

\section{RESULTS AND DISCUSSION}

\section{Neonicotinoid determination in Bucharest WWTP}

The presence, behavior and elimination of neonicotinoids were studied in the treatment plant in Bucharest. It was found that the following compounds were present in the influent: imidacloprid (60.8-80.2 $\mathrm{ng} / \mathrm{L})$, thiamethoxan (16.4-23.6 ng/L), dinotefuran (4.4-
$6 \mathrm{ng} / \mathrm{L})$ and acetamiprid (0.97-2.4 ng/L) (Table 6). It was also observed that the effluent was contaminated with imidacloprid (mean 53.3 $\mathrm{ng} / \mathrm{L})$, thiamethoxan (14.6 $\mathrm{ng} / \mathrm{L})$, dinotefuran (3.7ng/L) and acetamiprid (1.95 ng/L) [25].

Table 6. Neonicotinoid concentrations in influent, effluent and decanted samples, Bucharest WWTP

\begin{tabular}{ccccccccccccccccc}
\hline (ng/L) & \multicolumn{3}{c}{ Day 1 } & \multicolumn{1}{c}{ Day 2 } & \multicolumn{4}{c}{ Day 3 } & \multicolumn{1}{c}{ Day 4 } & \multicolumn{3}{c}{ Average } \\
\hline & Inf. & Dec & Efl. & Inf. & Dec. & Efl. & Inf. & Dec & Efl. & Inf. & Dec & Efl. & Inf. & Dec & Efl. \\
\hline Dinotefuran & 4.4 & 3.1 & 3.9 & nd & nd & nd & 6.0 & 5.2 & 4.3 & 5.0 & 2.8 & 3.5 & 5.1 & 3.7 & 3.9 \\
Thiametoxan & 23.6 & 18 & 17 & 17 & 18.2 & 15.4 & 17 & 14 & 13.5 & 16 & 13.1 & 13.1 & 19 & 16 & 15 \\
Imidacloprid & 72.0 & 62 & 55 & 61 & 64.8 & 55.2 & 80 & 59 & 63.2 & 64 & 38.1 & 41.5 & 69 & 56 & 54 \\
Acetamiprid & nd & nd & nd & nd & nd & nd & 2.4 & 2.5 & 2.0 & 1.0 & 1.4 & 0.68 & 1.6 & 1.9 & 1.3 \\
\hline
\end{tabular}


Neonicotinoids were determined in all samples taken from WWTP plant in Bucharest.

The highest average concentrations belonged to imidacloprid in all 3 matrices: $69.3 \mathrm{ng} / \mathrm{L}$ in influent, $55.9 \mathrm{ng} / \mathrm{L}$ in decanted and $53.6 \mathrm{ng} / \mathrm{L}$ in effluent followed by thiamethoxam $18.6 \mathrm{ng} / \mathrm{L}$ in influent, $15.8 \mathrm{ng} / \mathrm{L}$ in decanted and $14.7 \mathrm{ng} / \mathrm{L}$ in effluent. The lowest concentrations were determined for acetamiprid: influent $1.69 \mathrm{ng} / \mathrm{L}$, decanted $1.9 \mathrm{ng} / \mathrm{L}$ and effluent $1.3 \mathrm{ng} / \mathrm{L}$. These values correlate with the short half-life of acetamiprid 4.7 days, which is the lowest, and imidacloprid has a half-life by dissipation in water of 30 days. 2 compounds (nitenpyram and clothianidin) were not detected in the analyzed wastewater samples. The decanted waters from the station were contaminated with the following compounds (average concentrations in the 4 days of study): dinotefuran $3.7 \mathrm{ng} / \mathrm{L}$, imidacloprid $55.9 \mathrm{ng} / \mathrm{L}$, acetamiprid $1.95 \mathrm{ng} / \mathrm{L}$ thiamethoxam $15.8 \mathrm{ng} / \mathrm{L}[25,27,28]$.

The elimination rate $(\%)$ of the neonicotinoid insecticides in WWTP was determined with the next equation (1):

$$
\text { Elimination }(\%)=\frac{C_{i n}-C_{e f}}{C_{i n}} \cdot 100
$$

All detected compounds were unsatisfactorily removed in the treatment plant. So, acetamiprid and dinotefuran had an elimination rate of $23.2 \%$, thiamethoxam was eliminated only $20.3 \%$ while imidacloprid had an elimination yield of 22.4 (Table 7).

Table 7. Neonicotinoid removal rates in Bucharest WWTP

\begin{tabular}{ccccccc}
\hline \multicolumn{7}{c}{ Effluent removal (\%) } \\
\hline Compound/Day & Day 1 & Day 2 & Day 3 & Day 4 & Average & Average \\
\hline Dinotefuran & 11.36 & - & 28.33 & 30 & 23.23 & 27.90 \\
Thiametoxan & 28.81 & 9.94 & 22.41 & 20.12 & 20.32 & 14.90 \\
Imidacloprid & 23.89 & 9.21 & 21.2 & 35.46 & 22.44 & 19.30 \\
Acetamiprid & - & - & 16.67 & 29.9 & 23.29 & -15.70 \\
\hline
\end{tabular}

Comparing the concentrations of the decanted with those of the influent, it can be observed that the neonicotinoids are eliminated unsatisfactorily at this stage of treatment $(14.9 \%$ for thiametoxam, imidacloprid $19.3 \%$ and dinotefuran $27.9 \%$ ). Removal percentages of neonicotinoids in the secondary (biological) stage are slightly higher than those in the mechanical decantation stage. Still, it is observed that the bio-chemical processes applied in the degradation of the neonicotinoids in the treatment plant are inefficient and require the development of new technologies for

Beta-blockers determination in municipal WWTPs

The SPE-LC-MS MS method developed and validated within a "Nucleu" project and previously published [17], was applied to determine the beta-blockers in the influent and effluent of 3 municipal WWTPs, in Buzau, Braila and Focsani, in 3 successive days. The influent samples showed high concentrations of atenolol (29-623 ng/L), betaxolol (6.2-144 ng/L), bisoprolol (5.1-301 ng/L), propranolol (7- wastewater treatment that will allow the removal of these compounds. The presence of neonicotinoids at levels of tens of $n g / L$ in the effluent of the treatment plant indicates a high risk of these compounds to enter the receiving surface waters through the effluents discharged from the station into the Dambovita River. The life of aquatic microorganisms most sensitive to neonicotinoids may be irreversibly affected by the toxicity of these compounds. Morrissey et al. have established that concentrations of neonicotinoids over $35 \mathrm{ng} / \mathrm{L}$ affect aquatic invertebrates [6].

$52.5 \mathrm{ng} / \mathrm{L}$ Table 8). The compounds with the highest concentrations were atenolol $(623 \mathrm{ng} / \mathrm{L}$ in Focsani WWTP) followed by bisoprolol 309ng/L also in Focsani. The effluent samples showed the following beta-blockers: bisoprolol (2.7-170 ng/L), atenolol (17-300 $\mathrm{ng} / \mathrm{L})$, propranolol (5.1-41 ng/L) and betaxolol (3.1-40 $\mathrm{ng} / \mathrm{L})[16,17]$. 
Table 8. The beta-blockers concentrations in Braila, Buzau and Targu-Jiu WWTPs

\begin{tabular}{clcccccc}
\hline \multirow{2}{*}{ ng/L } & \multirow{2}{*}{ WWTP } & $\begin{array}{c}\text { Day 1, } \\
\text { Inf. }\end{array}$ & $\begin{array}{c}\text { Day 1, } \\
\text { Efl. }\end{array}$ & $\begin{array}{c}\text { Day 2, } \\
\text { Inf. }\end{array}$ & $\begin{array}{c}\text { Day 2, } \\
\text { Efl. }\end{array}$ & $\begin{array}{c}\text { Day 3, } \\
\text { Inf. }\end{array}$ & $\begin{array}{c}\text { Day 3, } \\
\text { Efl. }\end{array}$ \\
\hline \multirow{3}{*}{ Atenolol } & Braila & 148.6 & 59 & 135 & 49 & 143.5 & 59 \\
& Focsani & 396.5 & 190 & 266.8 & 109 & 623 & 300 \\
& Targu-Jiu & 42.2 & 25 & 93.1 & 44 & 29 & 17 \\
& Braila & 149.4 & 69 & 105.6 & 49 & 158.6 & 77 \\
Bisoprolol & Focsani & 102 & 55 & 57.3 & 29 & 309 & 170 \\
& Targu-Jiu & 5.1 & 2.8 & 6 & 3.4 & 8.3 & 4.2 \\
& Braila & 52.8 & 21 & 51 & 23 & 47.4 & 29 \\
Betaxolol & Focsani & 77.6 & 24 & 9.1 & 3.1 & 144 & 40 \\
& Targu-Jiu & 6.2 & 3.2 & 8.4 & 4.3 & 9.1 & 5.1 \\
& Braila & 29 & 21 & 46 & 34 & 52.5 & 41 \\
& Focsani & 24 & 17 & 13.4 & 9 & 51 & 34 \\
& Targu-Jiu & 7 & 5.1 & 10.8 & 8 & 8.2 & 6.2 \\
\hline
\end{tabular}

The efficiency of elimination of beta-blockers in the studied stations was estimated using the mathematical equation 1. High eliminations were observed in the following stations: Focsani for betaxolol $69.1 \%$ and Braila for atenolol $60.9 \%$ (Table 9).

Average (acceptable) eliminations were obtained at the stations: Braila for bisoprolol (52.9\%) and betaxolol 51.3\%, Focsani for atenolol 54.3\%, bisoprolol 46.8\%, and Targu-Jiu, (47\% for betaxolol and $45.9 \%$ for atenolol. For propranolol low eliminations were obtained: Focsani $31.8 \%$, Braila 25.2\% [16, 17]

Table 9. Treatment efficiency of WWTPs for Beta-blockers

\begin{tabular}{lccc}
\hline $\begin{array}{c}\text { Removal rate } \\
\text { (average), } \%\end{array}$ & Braila & Focsani & Targu-Jiu \\
\hline Atenolol & 60.96 & 54.36 & 44.97 \\
Bisoprolol & 52.95 & 46.82 & 45.94 \\
Betaxolol & 51.32 & 69.08 & 47.05 \\
Propanolol & 25.19 & 31.78 & 25.82 \\
\hline
\end{tabular}

High eliminations were observed in the following stations: Focsani for betaxolol $69.1 \%$ and Braila for atenolol $60.9 \%$. Satisfactorily eliminations were obtained at the stations: Braila for bisoprolol (52.9\%) and betaxolol 51.3\%, Focsani for atenolol $54.3 \%$, bisoprolol $46.8 \%$, and Targu-Jiu, $47 \%$ for betaxolol and $45.9 \%$ for atenolol.

The high concentrations of beta-blockers in the treatment plants (hundreds of $n g / L$ ) are due to the intense prescription and use of compounds in cardiovascular diseases, which ranks first in the

\section{CONCLUSIONS}

In this review are presented the main chromatographic methods developed previously for the quantitative determination of some classes of emerging contaminants (neonicotinoid insecticides and beta-blockers compounds) from world as cause of death. On the other hand, it is known that some beta-blockers are eliminated non-metabolized in the human body. The presence of these contaminants (atenolol 300 $\mathrm{ng} / \mathrm{L}$ and bisoprolol $170 \mathrm{ng} / \mathrm{L}$ ) clearly suggests their high penetration potential into the receiving aquatic environment. Contaminated effluents are continuously discharged into rivers whose water is used to produce drinking water for the resident population of these basins (Jiu, Danube), thus generating a potential risk to human health.

various categories of waters (influent, effluent municipal wastewater treatment plants). Thus, the optimal parameters of the solid phase extraction (SPE), chromatographic separation (LC) and mass spectrometric detection (MS/MS) 
were underlined. Furthermore, we present and discuss the results obtained in analytical studies regarding the contamination of urban wastewater with beta-blockers and neonicotinoids.

It was found that the neonicotinoids are unsatisfactorily removed from the municipal wastewater treatment plant (elimination $<23 \%$ ) and thus they enter from the effluents into the receiving surface waters. In the case of betablockers, it was found that the different investigated WWTPs eliminate these pollutants with variable degree: acceptable for atenolol and betaxolol (60.9-69.1\%), satisfactory in the case of atenolol and bisoprolol (45.9 - 54.3\%) and unsatisfactory for propranolol (25.2 - 31.8\%).

\section{ACKNOWLEDGEMENTS}

The authors acknowledge the financial support offered by National Research Program "Nucleu" through contract number 20N/2019, Project code PN 19040101.

\section{REFERENCES}

[1] MANZETTI, S., VAN DER SPOEL, D., Ecotoxicology, 24, 2015, p.1799.

[2] STASINAKIS, A. S., Bioresour. Technol., 121, 2012, $\quad$ p. 432, https://doi.org/10.1016/j.biortech.2012.06.074.

[3] JESCHKE, P., NAUEN, R., SCHINDLER, M., ELBERT, A., J. Agric. Food Chem., 59, 2011, $\mathrm{p}$. 2897 , https://doi.org/10.1021/jf101303g.

[4] SPIVAK, M., MADER, E., VAUGHAN, M., EULISS, N. H., Environ. Sci. Technol, 45, no. 1, 2010, p. 34, https://doi.org/10.1021/es101468w.

[5] SANCHEZ-BAYO, F., HYNE, R. V., Chemosphere, 99, 2014, p. 143, 10.1016/j.chemosphere.2013.10.051.

[6] MORRISSEY, C. A., MINEAU, P., DEVRIES, J. H., SANCHEZ-BAYO, F., LIESS, M., CAVALLARO M. C., LIBER, K., Environ. Int., 74, 2015, p. 291, 10.1016/j.envint.2014.10.024.

[7] HLADIK, M. L., KOLPIN, D. W., KUIVILA, K. M., Environ. Pollut., 193, 2014, p.189,

https://doi.org/10.1016/j.envpol.2014.06.033.

[8] ***Commission Implementing Decision (EU) 2015/495 of 20 March 2015, Establishing a Watch List of Substances for Union-Wide Monitoring in the Field of Water Policy Pursuant to Directive 2008/105/EC of the European Parliament and of the Council, https://eur-lex.europa.eu/legal-

content/EN/TXT/?uri=uriserv\%3AOJ.L_.2015.0 78.01.0040.01.ENG. [09.02.2020].

[9] ***Commission Implementing Regulation (EU) 785 of 29 May 2018, Amending Implementing Regulation (EU) No 540/2011 as regards the conditions of approval of the active substance thiamethoxam, Official Journal of the European Union, L 132/40, 30.05.2018, https://eur-lex.europa.eu/legal-

content/EN/TXT/PDF/?uri=CELEX:32018R078 3\&from=DA. [16.03.2020].

[10] CLEUVERS, M., Chemosphere, 59, no. 2, 2005 , $\mathrm{p}$.

199 ,

10.1016/j.chemosphere.2004.11.090.

[11] GABET-GIRAUD, V., MIEGE, C., CHOUBERT, J. M., MARTIN RUEL, S., COQUERY, M., Sci. Total Environ., 408, no. 19, 2010, p. 4257, 10.1016/j.scitotenv.2010.05.023.

[12] STANKIEWICZ, A., GIEBULTOWICZ, J., STEFANSKI, M., SIKORSKA, K., WROCZYNSKI, P., NALECZ-JAWECKI, G., Environ. Toxicol. Pharmacol., 39, no. 2, 2015, p. 906, 10.1016/j.etap.2015.03.002.

[13] MAURER, M., ESCHER, B. I., RICHLE, P., SCHAFFNER, C., ALDER, A. C., Water Res., 41, no. 7, 2007, p.1614, 10.1016/j.watres.2007.01.004

[14] *** Chemicalize, Instant cheminformatic solutions, https://chemicalize.com/\#/calculation. [20.03.2020].

[15] TERNES, T. A., Water Res., 32, no. 11, 1998, p. 3245, https://doi.org/10.1016/S00431354(98)00099-2.

[16] IANCU, V. I., RADU, G. L., SCUTARIU, R., CHIRIAC, L. F, GALAON, T., PETRE, J., Rev. Chim., 70, no. 12, 2019, p. 4607, https://doi.org/10.37358/RC.19.12.7801

[17] IANCU, V. I., RADU, G. L., SCUTARIU, R., Anal. Methods, 12, 2019, p. 1504, https://doi.org/10.1039/C9AY01597C.

[18] MASZKOWSKA, J., STOLTE, S., KUMIRSKA, J., LUKASZEWICZ, P., MIODUSZEWSKA K., PUCKOWSKI A., M. 
CABAN, M. WAGIL, P. STEPNOWSKI AND A. BIALK-BIELINSKA, Sci. Total Environ., 493, 2014 p.

1122 , https://doi.org/10.1016/j.scitotenv.2014.06.023.

[19] FARRE, M., PEREZ, S., KANTIANI, L., BARCELO, D., TRAC-Trends Anal. Chem., 27, no. 11, 2008, p. 991, https://doi.org/10.1016/j.trac.2008.09.010.

[20] BEHERA, S. K., KIM, H. W., OH, J.-E., PARK, H.-S., Sci. Total Environ., 409, no. 20, 2011, p. 4351, 10.1016/j.scitotenv.2011.07.015. [21] VERLICCHI, P., AUKIDY, M. A., ZAMBELLO, E., Sci. Total Environ., 429, 2012, p.123, 10.1016/j.scitotenv.2012.04.028. [22] NODLER, K., LICHA, T., BESTER K., SAUTER, M., J. Chromatogr. A, 1217, no. 15, 2010 , p. 6511 , https://doi.org/10.1016/j.chroma.2010.08.048.
[23] AL-KHAZRAJY, O. S. A., BOXALL, A. B. A., Anal. Methods, 9, 2017, p. 4190, https://doi.org/10.1039/C7AY00650K.

[24] DE OLIVEIRA, J. A., IZEPPI L. J. P., LOOSE R. F., MUENCHEN D. K., PRESTES O. D., ZANELLA, R., Anal. Methods, 11, 2019, p. 2333, https://doi.org/10.1039/C9AY00289H. [25] IANCU, V.-I., RADU, G.-L., Anal. Methods, 10, 2018, p. 2691, https://doi.org/10.1039/C8AY00510A

[26] RADJENOVIC, J., PETROVIC, M., BARCELO, D., Water Res., 43, no. 3, 2009, p. 831, 10.1016/j.watres.2008.11.043.

[27] IANCU, V. I., PETRE, J., GALAON, T., RADU, G. L., Rev. Chim., 70, no. 1, 2019, p. 313, https://doi.org/10.37358/RC.19.1.6907. [28] IANCU, V. I, GALAON, T., NICULESCU, M., LEHR, C. B, Rev. Chim., 68, no. 8, 2017, p. 1716, https://doi.org/10.37358/RC.17.8.5751 